\title{
MODAL SOSIAL PENGURUS KARANG TARUNA DALAM MENANGANI KEMISKINAN DI DESA BUNISARI KECAMATAN WARUNGKONDANG KABUPATEN CIANJUR
}

\author{
Irma Dewi Istikomah \\ Politeknik Kesejahteraan Sosial Bandung \\ Raden Enkeu Agiati \\ Politeknik Kesejahteraan Sosial Bandung, agiatienkeu@yahoo.co.id \\ Aries Effendi Ilyas \\ Politeknik Kesejahteraan Sosial Bandung
}

\begin{abstract}
Social capital is an asset that is formed through social relations among people in order to achieve economic and social benefits. Social capital refers to the potential network, norms, and trustworthiness of community productivity. The purpose of this research is to explore about: 1) characteristics of the subject, 2) the subject's belief in dealing with poverty, 3) the norm embraced by the subject in dealing with poverty, and 4) the subject social network in dealing with poverty. The method used in this research is a qualitative method. The data source used is the primary and secondary data source. Data collection techniques use in-depth interviews, participatory observation, and documentation studies. The validity check of the data used is the validity of transferability, dependability, degrees of trust (credibility), and Confirmability with the technique of participation extension, persistence of observation, tiangulation, and peer inspection. The data analysis technique used is a qualitative data analysis technique. The results showed that the social capital of the cadets to deal with the problem of poverty needs to be strengthened, in the event that the trust has been strong, while for the norm and social network the management of coral Taruna is still weak due to the ignorance of the management of the coral Taruna about the importance of making a joint commitment to deal It is therefore offered the program "discussion Forum for management of Coral Taruna Village Bunisari to strengthen social capital" in the effort to deal with poverty.
\end{abstract}

Keywords: Social capital, Coral Taruna, poverty, and discussion Forum

\begin{abstract}
ABSTRAK
Modal sosial adalah aset yang terbentuk melalui relasi sosial diantara manusia dalam rangka mencapai keuntungan ekonomi maupun manfaat sosial. Modal sosial merujuk pada jejaring, norma, dan kepercayaan yang berpotensi pada produktivitas masyarakat. Tujuan penelitian ini adalah untuk menggali tentang: 1) Karakteristik subjek, 2) Kepercayaan Subjek dalam Menangani Kemiskinan, 3) Norma yang dianut Subjek dalam Menangani Kemiskinan, dan 4) Jejaring Sosial Subjek dalam Menangani Kemiskinan. Metode yang digunakan dalam penelitian ini adalah metode kualitatif. Sumber data yang digunakan adalah sumber data primer dan sekunder. Teknik pengumpulan data menggunakan wawancara mendalam, observasi partisipatif, dan studi dokumentasi. Pemeriksaan keabsahan data yang digunakan adalah pemeriksaan keabsahan keteralihan (transferability), kebergantungan (dependability), derajat
\end{abstract}


kepercayaan (credibility), dan Konfirmabilitas (Confirmability) dengan teknik Perpanjangan Keikutsertaan, ketekunan pengamatan, tiangulasi, dan pemeriksaan sejawat. Teknik Analisis data yang digunakan adalah teknik analisis data kualitatif. Hasil Penelitian menujukkan bahwa modal sosial pengurus karang taruna untuk menangani masalah kemiskinan perlu dikuatkan, dalam hal kepercayaan sudah kuat sedangkan untuk norma dan jejaring sosial pengurus karang taruna masih lemah disebabkan ketidaktahuan pengurus karang taruna mengenai pentingnya membuat komitmen bersama dalam menangani kemiskinan dan ketidaktahuan pengurus karang taruna untuk membuat strategi membangun jejaring sosial baik internal maupun lintas sektoral. Oleh karena itu ditawarkan program "Forum Diskusi bagi Pengurus Karang Taruna Desa Bunisari untuk Menguatkan Modal Sosial” dalam usaha menangani kemiskinan.

Keywords: Modal Sosial, Karang Taruna, Kemiskinan, dan Forum Diskusi

\section{PENDAHULUAN}

Karang Taruna adalah organisasi sosial kepemudaan yang menjadi wadah pengembangan bagi generasi muda Indonesia dan juga menjadi wadah untuk peningkatan kepedulian sosial generasi muda kepada masyarakat sekitar, cakupan wilayah karang taruna adalah desa atau kelurahan atau komunitas adat sederajat. Sesuai dengan kedudukan karang taruna secara organisasi bersifat lokal, otonom, dan berdiri sendiri, sehingga hubungan antar karang taruna atas dasar kesetaraan/kesederajatan.

Karang taruna memiliki kedudukan yang strategis sehingga memudahkan untuk melaksanakan tujuan mengenai pengembangan sumber daya manusia seperti generasi muda, dan tanggung jawab untuk turut aktif berusaha menangani masalah kesejahteraan sosial di lingkungan sekitar karang taruna. Karang taruna merupakan tempat diselenggarakannya berbagai upaya atau kegiatan untuk meningkatkan dan mengembangkan cipta, rasa, karsa, dan karya generasi muda dalam rangka pengembangan sumber daya.

Karang taruna dalam menanggulangi masalah kesejahteraan sosial dapat diwujudkan dengan program dan kegiatan baik yang bersifat preventif, rehabilitatif maupun pengembangan potensi generasi muda. Umumnya kegiatan yang mempunyai fungsi pencegahan adalah kegiatan pengisian waktu luang dengan yang positif seperti rekreasi, olahraga, kesenian dan sebagainya.

Program yang bersifat rehabilitatif atau pemulihan artinya karang taruna berperan menyelenggarakan rujukan atau pendampingan dan advokasi sosial kepada masyarakat yang mengalami masalah kesejahteraan sosial seperti korban napza, korban bencana, fakir miskin, anak terlantar, lanjut usia terlantar, perempuan rawan sosial ekonomi, disabilitas dan sebagainya. Kemudian untuk program yang sifatnya pengembangan dapat diartikan sebagai upaya memperkuat, memperluas, mempertajam, dan mengembangkan segala sumber daya untuk mampu meningkatkan taraf hidup dan melaksanakan usaha-usaha kesejahteraan sosial.

Kerja sama pengurus karang taruna sangat dibutuhkan guna mewujudkan program-program tersebut, maka organisasi karang taruna membutuhkan pengurus karang taruna sebagai penggerak utama kegiatan. Pengurus karang taruna 
merupakan ujung tombak organisasi karang taruna, apabila pengurus karang taruna bekerja dengan baik dan aktif maka aktif pula organisasi karang taruna tersebut. Namun apabila kinerja pengurus karang taruna belum maksimal maka usaha untuk mewujudkan program-program tersebut akan terkendala.

Pemerintah memberikan klasifikasi karang taruna berdasarkan kondisi objektif dari keorganisasian dan aktivitas karang taruna meliputi: kelembagaan, program kerja, kegiatan, sarana prasarana, sistem dukungan dan partisipasi dari setiap unsur yang terkait dengan karang taruna, dalam kondisi ini pengurus karang taruna sangat berperan dalam membawa arah gerak karang taruna. Pengklasifikasian yang diberikan pemerintah bertujuan untuk pemberdayaan dan memotivasi pengurus dan anggota karang taruna agar lebih kreatif dan dinamis dalam mengelola organisasinya.

Klasifikasi karang taruna yang dibuat pemerintah dimulai dari karang taruna tumbuh adalah karang taruna secara formal telah tumbuh dan tersusun kepengurusannya, namun kegiatannya sangat sederhana dan belum terprogram, karang taruna berkembang adalah karang taruna yang secara organisatoris maupun administratif sudah teratur dan terpola dengan mekanisme sistematis, selanjutnya karang taruna maju adalah karang taruna yang dilihat secara administratif, organisatoris, kepengurusan dan programprogram karang taruna telah berjalan baik, teratur, dan berkesinambungan serta prospek program ke depannya sudah jelas yang terakhir adalah karang taruna percontohan/berprestasi yaitu karang taruna maju yang telah melaksanakan program untuk menciptakan generasi muda di lingkungan karang taruna yang mampu mengembangkan program-program pembangunan nasional.

Indikator setiap kelasnya sudah dijelaskan dengan rinci, untuk mencapai tingkat kelas karang taruna yang semakin baik dan berdampak luas terhadap masyarakat maka dibutuhkan usaha lebih keras dari anggota karang taruna, lebih khusus usaha dari pengurus karang taruna untuk mengelola organisasi. Mengelola organisasi dibutuhkan kerjasama, saling percaya, nilai-nilai bersama dan juga jejaring sosial yang kuat diantara para pengurus karang taruna agar kegiatan yang dilakukan karang taruna benar-benar sesuai dengan yang diharapkan dan maksimal.

Hubungan antar pengurus karang taruna sangat mempengaruhi kondisi organisasi karang taruna. Hubungan antar individu yang dilandasi kepercayaan, norma-norma, dan jejaring sosial disebut modal sosial. Relasi kerja sama diantara pengurus karang taruna bisa juga disebut dengan modal sosial pengurus karang taruna. Modal sosial ini sangat mendukung pencapaian tujuan organisasi karang taruna, sehingga semakin tinggi modal sosial yang dimiliki pengurus karang taruna maka akan semakin tinggi pula ketercapaian tujuan karang taruna.

Modal sosial pengurus karang taruna didalamnya terdapat kebersamaan dan energi kelompok, jika kebersamaan dan energi kelompok hilang maka hilang juga modal sosialnya. Modal sosial ini memang sulit terlihat tetapi bisa dirasakan dan diketahui dari pengaruh yang dihasilkannya, sehingga, setiap hasil yang dicapai karang taruna merupakan hasil juga dari modal sosial pengurus karang taruna tersebut.

Modal sosial memberikan kekuatan atau daya dalam beberapa kondisi sosial di tengah masyarakat. Modal sosial ini 
membantu masyarakat untuk memfasilitasi dan membangun kerjasama melalui interaksi dan komunikasi yang harmonis dan kondusif. Modal sosial timbul dari interaksi antara orang-orang dalam suatu komunitas. Pengukuran modal sosial dapat dilihat dari interaksi baik individual maupun institusional, seperti terciptanya atau terpeliharanya kepercayaan antar warga masyarakat.

Modal sosial bersifat kumulatif dan bertambah dengan sendirinya (selfreinforcing) karena itu modal sosial tidak akan habis jika dipergunakan, melainkan semakin meningkat, tanpa disadari jika para pengurus karang taruna terus membangun relasi, hubungan, kerjasama diantara pengurus karang taruna guna kemajuan dan program-program karang taruna maka modal sosial diantara pengurus karang taruna juga akan meningkat. Sedangkan jika relasi dan hubungan tidak dibangun dengan konsisten dan berkelanjutan maka modal sosial dapat hilang karena tidak dipergunakan.

Kemiskinan merupakan masalah sosial yang masih menjadi musuh utama dalam usaha mencapai kesejahteraan sosial. Hampir semua masalah sosial berakar dari kemiskinan. Kemiskinan terjadi di berbagai daerah salah satunya di Jawa Barat. Berdasarkan data Badan Pusat Statistika Jawa Barat tahun 2019 jumlah penduduk miskin di Jawa Barat sebanyak 3,39 juta jiwa dan salah satu kabupaten yang memiliki jumlah tinggi adalah Kabupaten Cianjur sebanyak 207 ribu jiwa, ini menunjukkan populasi penduduk miskin di Cianjur cukup tinggi, tidak memungkiri juga terjadi di Desa Bunisari Kecamatan Warungkondang, Kabupaten Cianjur kemiskinan masih menjadi masalah utama warga masyarakat. Akses pendidikan juga masih sulit untuk didapatkan, sehingga sebagian masyarakat di desa itu memiliki pendidikan yang tergolong rendah.

Masyarakat yang memiliki modal sosial tinggi cenderung bekerja secara gotong royong, merasa aman untuk berbicara dan mampu mengatasi perbedaan-perbedaan. Sedangkan masyarakat yang memiliki modal sosial rendah akan tampak kecurigaan satu sama lain, serta adanya pembedaan kelompok. Masyarakat di Desa Bunisari, Kecamatan Warungkondang, Kabupaten Cianjur adalah masyarakat pedesaan dan memiliki karakteristik homogen karena mayoritas bekerja sebagai petani dan mereka juga biasanya memiliki kebiasaan gotong royong yang kuat. Masyarakat di desa pada umumnya memiliki modal sosial yang tinggi. Oleh karena itu peneliti tertarik mengkaji bagaimana dengan modal sosial yang dimiliki para pemuda disana khususnya pengurus karang taruna.

Hasil pencarian literatur menunjukkan bahwa Karang Taruna Desa Bunisari, Kecamatan Warungkondang, Kabupaten Cianjur memiliki kekhasan dibanding karang taruna lainnya yaitu memiliki usaha pengolahan sampah menggunakan sistem bank sampah, sehingga dapat memberikan penghasilan tambahan untuk meningkatkan perekonomian masyarakat, selain itu anggota karang taruna juga beberapa ada yang sudah memiliki usaha ternak lele, ada juga yang memiliki usaha catering dan ada yang memiliki usaha pembuatan keripik. Karang taruna juga bekerja sama dengan masyarakat dalam penjualan produk peci rajut. Melalui berbagai usaha produktif tersebut maka peneliti ingin mengkaji apakah karang taruna tersebut memiliki kontribusi besar dalam penanganan kemiskinan di Desa Bunisari.

Penelitian ini dilatarbelakangi oleh keingintahuan terhadap hubungan antara 
modal sosial pengurus karang taruna dengan salah satu usaha kesejahteraan sosial yaitu penanganan kemiskinan di Desa Bunisari. Peneliti ingin mengkaji apakah modal sosial karang taruna juga mempengaruhi kemiskinan dalam masyarakat Desa Bunisari. Masyarakat di daerah pedesaan pada umumnya memiliki hubungan yang erat dan mereka lebih mengenal satu sama lain dibandingkan dengan masyarakat perkotaan yang lebih individualis dan pada umumnya memiliki modal sosial rendah.

Berdasarkan latar belakang masalah penelitian tersebut, rumusan masalah penelitian ini adalah, "Bagaimana Modal Sosial Pengurus Karang Taruna dalam Menangani Kemiskinan di Desa Bunisari Kecamatan Warungkondang Kabupaten Cianjur?" Selanjutnya perumusan masalah ini difokuskan pada : 1) Bagaimana karakteristik subjek?,2) Bagaimana kepercayaan (trust) subjek dalam menangani kemiskinan?,,3) Bagaimana norma (norms) yang dianut subjek dalam menangani kemiskinan?, dan 4) Bagaimana jejaring sosial (social networks) subjek dalam menangani kemiskinan?.

Putnam (dalam Sunyoto Usman; 2018:30) adalah sebagai produk relasi manusia satu sama lain, khususnya relasi yang intim dan konsisten. Modal sosial merujuk pada jejaring, norma, dan kepercayaan yang berpotensi pada produktivitas masyarakat. Namun demikian modal sosial berbeda dengan modal finansial karena modal sosial memiliki sifat kumulatif dan bertambah dengan sendirinya (self-reinforcing), karenanya modal sosial tidak akan habis jika dipergunakan, melainkan akan semakin meningkat. Rusaknya modal sosial lebih sering disebabkan bukan karena di pakai melainkan karena ia tidak dipergunakan. Selain itu modal sosial dapat dikatakan sebagai suatu perekat bagi setiap individu, dalam bentuk kepercayaan (trust) atau nilai-nilai positif yang menghargai perkembangan atau prestasi, lalu norma sosial dan obligasi serta jejaring sosial yang menjadi wadah kegiatan sosial, terutama dalam bentuk asosiasi-asosiasi sukarela (voluntary associations). Modal sosial dijelaskan sebagai institusi lokal yang melibatkan kepercayaan sosial (social trust), norma- norma (norms) dan jejaring (networks) yang mendorong pada sebuah kolaborasi sosial (koordinasi dan kooperasi) untuk kepentingan bersama. Hal ini mengandung pengertian bahwa diperlukan adanya suatu social networks atau jejaring sosial yang ada dalam masyarakat, dan norma yang mendorong produktivitas komunitas.

Jousari Hasbullah (2006:9), inti modal sosial terletak pada bagaimana kemampuan masyarakat dalam suatu kelompok untuk bekerjasama membangun suatu jejaring untuk mencapai tujuan bersama. Kerjasama tersebut diwarnai oleh suatu pola interelasi yang timbul diatas kepercayaan (trust) yang ditopang oleh norma-norma dan nilai-nilai sosial positif dan kuat. Sedangkan menurut Eva Cox (dalam Jousari Hasbullah; 2006:6) modal sosial merupakan suatu rangkaian proses hubungan antar manusia yang ditopang oleh norma-norma, jejaring, dan kepercayaan sosial yang memungkinkan efisien dan efektifnya koordinasi dan kerjasama untuk keuntungan dan kebijakan bersama. Merujuk pada pernyataan Robert M.Z. Lawang (2005:45) menjelaskan bahwa terdapat tiga konsep dasar yang melekat dalam pembahasan kapital sosial (modal sosial) yaitu kepercayaan, norma, dan jejaring. 
Putnam (dalam Sunyoto Usman; 2018:30) menyatakan modal sosial dibangun melalui jejaring sosial yang menjadi wadah kegiatan sosial terutama dalam bentuk asosiasi-asosiasi sukarela, Putnam percaya asosiasi sukarela memiliki peran penting dalam upaya mengembangkan modal sosial. Asosiasi sukarela bukan hanya aktif menyalurkan informasi (flow of information) tetapi juga menjadi ajang berinteraksi dan melakukan transaksi diantara aktor-aktor yang terhimpun di dalamnya. Interaksi dan transaksi tersebut selanjutnya mendorong mereka mengembangkan norma-norma yang memfasilitasi kerja sama saling menguntungkan (reciprocal relationship). Asosiasi sukarela dan hubungan saling menguntungkan tersebut adalah dua faktor yang dipercaya mampu menumbuhkan trust atau nilai-nilai positif yang menghargai perkembangan. Selanjutnya trust memperkuat hubungan saling menguntungkan dan asosiasi-asosiasi sukarela sehingga terbentuk jejaring sosial yang kuat karena jejaring baru dapat diketahui melalui kelompok atau jejaring kerja yang terdapat pada suatu masyarakat dikarenakan kelompok atau jejaring kerja dapat merepresentasikan kondisi jejaring yang terjalin pada suatu masyarakat.

Karang Taruna merupakan organisasi yang dibentuk oleh masyarakat sebagai wadah generasi muda untuk mengembangkan diri, tumbuh, dan berkembang atas dasar kesadaran serta tanggung jawab sosial dari, oleh, dan untuk generasi muda, yang berorientasi pada tercapainya kesejahteraan sosial bagi masyarakat. Karang Taruna memiliki fungsi yang telah diatur pula dalam Permensos Nomor 25 Tahun 2019 Tentang Karang Taruna Bab II Pasal 7, yaitu: 1) fungsi Administrasi dan manajerial; 2)
Fasilitasi;, 3) Mediasi; 4) Komunikasi, informasi, dan edukasi; 5) Pemanfaatan dan pengembangan teknologi; 6) Advokasi sosial; 7) Motivasi; serta 8) Pendampingan; dan Pelopor.

Karang taruna mempunyai tujuan mewujudkan kesadaran tanggung jawab sosial setiap generasi muda dalam mengantisipasi, mencegah, dan menangkal berbagai permasalahan sosial khususnya dikalangan generasi muda dan mengembangkan kemampuan generasi muda dalam penyelenggaraan kesejahteraan sosial melalui rehabilitasi sosial, jaminan sosial, pemberdayaan sosial, dan perlindungan sosial.

Sehubungan fungsi dan tujuan karang taruna tersebut maka salah satu bentuk kontribusi nyata terhadap penanganan masalah sosial dalam hal ini masalah kemiskinan, bentuk pemberdayaan yang dapat dilakukan karang taruna adalah peningkatan terhadap manajemen organisasi, kapasitas sumber daya manusia, kapasitas sumber daya ekonomi, sarana dan prasarana serta jejaring kerja. Untuk mencapai pemberdayaan yang optimal maka karang taruna dapat bekerja sama dengan badan usaha, potensi sumber kesejahteraan sosial, lembaga pendidikan, dan masyarakat.

Kemiskinan merupakan masalah global artinya kemiskinan merupakan masalah yang dihadapi dan menjadi perhatian banyak orang di dunia ini. Meskipun dalam tingkatan yang berbeda, tidak ada satupun negara di jagat raya ini yang "kebal" dari kemiskinan. Kemiskinan bukan hanya dijumpai di Indonesia, India, Sri Lanka dan Argentina, melainkan pula ditemukan di Amerika Serikat, Jerman, Inggris, Australia, maupun Hongaria. Semua negara di dunia ini sepakat bahwa kemiskinan merupakan problema 
kemanusiaan yang menghambat kesejahteraan dan peradaban. kemiskinan Menurut Chambers (dalam Nanga; 2006), terutama di daerah pedesaan (rural poverty) adalah masalah ketidakberdayaan (powerlessness), keterisolasian (isolation), kerentanan (vulnarability) dan kelemahan fisik (physical weakness), dimana satu sama lain saling terkait dan mempengaruhi. Namun demikian, kemiskinan merupakan faktor penentu yang memiliki pengaruh paling kuat dari pada yang lainnya". Berdasarkan pemahaman tersebut, maka kemiskinan dapat menjadi penentu dan faktor dominan yang mempengaruhi persoalan kemanusiaan seperti keterbelakangan, kebodohan, ketelantaran, kriminalitas, kekerasan, perdagangan manusia, buta huruf, putus sekolah, anak jalanan, pekerja anak. Dengan demikian kemiskinan tidak bisa hanya dipandang dari satu sisi rendahnya pendapatan tetapi harus dari banyak aspek yang saling terkait sehingga bersifat multidimensi.

Pekerjaan sosial sangat erat hubungannya dengan kesejahteraan sosial. Keterkaitan keduanya yaitu ketika profesi pekerjaan sosial merupakan bidang profesi yang mandat utamanya adalah memberikan pelayanan sosial baik kepada individu, keluarga, kelompok, maupun masyarakat yang membutuhkan agar tercipta keberfungsian sosial. Individu yang belum berfungsi sosial dikatakan belum mencapai kesejahteraan sosial. Namun ketika individu, keluarga, kelompok maupun masyarakat telah mampu berfungsi sosial maka terciptalah kondisi kesejahteraan sosial tersebut. Berkaitan dengan masalahmasalah dibidang kesejahteraan sosial.

Pekerjaan sosial bertujuan untuk mencapai kesejahteraan individu, kelompok dan masyarakat secara umum. Tujuan pekerjaan sosial adalah : 1) meningkatkan kemampuan orang untuk menghadapi tugas-tugas kehidupan dan kemampuannya untuk memecahkan masalah-masalah yang dihadapinya, 2) meningkatkan orang dengan sistem sumber yang dapat menyediakan sumber-sumber pelayanan dan kesempatan-kesempatan dibutuhkan, 3) meningkatkan kemampuan pelaksanaan sistem tersebut secara efektif dan berkemanusiaan, dan 4) memberikan sumbangan bagi perubahan perbaikan dan perkembangan kebijaksanaan dan perundang-undangan. Dengan demikian sesuai tujuan pekerjaan sosial tersebut memiliki kewenanganan dalam penanggulangan kemiskinan.

\section{METODE}

Metode penelitian yang digunakan dalam penelitian ini adalah metode kualitatif, dengan metode kualitatif peneliti dapat menggambarkan secara mendalam tentang" Modal Sosial Pengurus Karang Taruna dalam Menangani Kemiskinan di Desa Bunisari Kecamatan Warungkondang Kabupaten Cianjur".

Sumber data yang digunakan dalam penelitian ini adalah sumber data primer yaitu informasi yang diperoleh secara langsung dari subjek penelitian terkait dengan modal sosial Pengurus Karang Taruna Desa Bunisari Kabupaten Cianjur. Selanjutnya sumber data sekunder yaitu sumber data yang berfungsi untuk mendukung adanya sumber data primer. Berkaitan dengan sumber data, Sumber data primer adalah data yang diperoleh secara langsung dari subjek penelitian, yaitu informasi yang diperoleh langsung dari subjek penelitian yang memiliki informasi berkaitan dengan Modal Sosial Pengurus Karang Taruna di Desa Bunisari Kecamatan Warung Kondang Kabupaten Cianjur. Penentuan subjek dalam penelitian 
ini dilakukan dengan purposive, purposive adalah pengambilan sumber data primer berdasarkan tujuan dilakukan atas pertimbangan bahwa sumber yang dipilih tersebut dapat memberikan informasi dan data yang diperlukan dalam penelitian. Adapun kriteria sumber data primer dalam penelitian ini antara lain: 1) pengurus aktif karang taruna Desa Bunisari Kecamatan Warungkondang Kabupaten Cianjur periode tahun 2018-2022, 2) memiliki kedudukan sebagai Ketua, Sekretaris, dan Bendahara, 3) berusia 17-45 tahun, 4) pendidikan minimal Sekolah Menengah Pertama, dan 5) bersedia memberikan informasi, memiliki kemauan serta kemampuan dalam pemberdayaan masyarakat. Berdasarkan kriteria tersebut maka dilakukan penentuan subjek dengan jumlah subjek utama sebanyak tiga orang yang terdiri dari ketua karang taruna, sekretaris karang taruna dan bendahara karang taruna.

Teknik pengumpulan data yang digunakan adalah : 1) Wawancara mendalam dilakukan oleh peneliti terhadap informan yang bersedia memberikan informasi. Wawancara mendalam dalam penelitian ini adalah proses untuk memperoleh keterangan untuk tujuan penelitian dengan cara tanya jawab antara peneliti dengan subjek penelitian dengan atau tanpa pedoman wawancara yang berkaitan dengan modal sosial pengurus karang taruna Desa Bunisari dalam menangani kemiskinan, 2) observasi partisipatif adalah teknik yang digunakan dengan pengamatan yang melibatkan subjek penelitian untuk mengetahui karakteristik pengurus karang taruna dan modal sosial pengurus karang taruna dalam penanganan kemiskinan di Desa Bunisari, dan 3) Studi dokumentasi, dilakukan oleh peneliti untuk mendapat informasi tentang bagaimana modal sosial pengurus karang taruna dalam menangani kemiskinan di Desa Bunisari Kecamatan Warungkondang Kabupaten Cianjur Jawa Barat.

Guna mempertanggungjawabkan data yang telah diperoleh secara akurat dan benar, diperlukan pemeriksaan keabsahan data. Teknik pemeriksaan keabsahan data yang digunakan adalah 1) Uji Kredibilitas Data (Credibility) adalah perpanjangan pengamatan, peneliti kembali ke lapangan untuk menguatkan hasil dari data yang sudah diperoleh sebelumnya. Uji kredibilitas terhadap hasil penelitian modal sosial pengurus karang taruna dalam menangani kemiskinan di Desa Bunisari Kecamatan Warungkondang Kabupaten Cianjur dilakukan dengan teknik ketekunan pengamatan, dan triangulasi yang dilakukan dengan cara: 1) triangulasi sumber dengan cara membandingkan perspektif subjek utama penelitian dengan perspektif lainnya yaitu dengan melakukan crosscheck dengan informan pendukung ketua BPD, Pembina Karang Taruna dan peneliti terdahulu, a) triangulasi waktu dengan cara mengajukan pertanyaan yang sama berkaitan dengan modal sosial pengurus karang taruna Desa Bunisari Kecamatan Warungkondang Kabupaten Cianjur kepada informan pendukung, serta c) triangulasi teknik dengan cara melakukan pengecekan penemuan hasil penelitian dengan beberapa teknik pengumpulan data melalui teknik wawancara mendalam, observasi partisipatif, dan studi dokumentasi. 2) Keteralihan (Transferability), yaitu pemeriksaan keabsahan data dengan teknik transferability memberikan uraian rinci, jelas, sistematis dan dapat dipercaya dalam penulisan laporan. 3) Ketergantungan (Dependability), yang dilakukan peneliti untuk mencegah terjadinya kesalahan 
interpretasi data, sehingga data yang ada mampu memberikan informasi yang valid dan dapat dipertanggungjawabkan,
Teknik Analisis data yang digunakan dalam penelitian ini adalah teknik analisis data kualitatif. dan setelah selesai di lapangan.

\section{HASIL PENELITIAN}

Desa Bunisari merupakan salah satu desa ini kesulitan mencari pekerjaan dan desa di Kecamatan Warungkondang berdampak pada meningkatnya angka Kabupaten Cianjur, Jawa Barat. Desa ini di kemiskinan di Desa Bunisari. Keberadaan dominasi oleh daerah perbukitan dan organisasi karang taruna yang berisi persawahan, sehingga mayoritas penduduk penduduk berusia produktif merupakan Desa Bunisari bekerja sebagai buruh tani. peluang bagi Desa Bunisari untuk Desa Bunisari memiliki banyak penduduk menangani masalah kemiskinan di Desa berusia produktif tetapi latar belakang Bunisari, didukung dengan kondisi alam dan pendidikan yang rendah dan minim karakter masyarakat pedesaan menjadi ketrampilan membuat banyak penduduk peluang untuk menangani kemiskinan.

Subjek penelitian ini terdiri atas tiga orang, antara lain Ketua Karang Taruna Desa Bunisari, Sekretaris Karang Taruna Desa Bunisari dan Bendahara karang taruna Desa Bunisari. Ketiga subjek merupakan Pengurus Inti Karang Taruna Desa Bunisari Kecamatan Warungkondang Kabupaten Cianjur periode 2018-2022. Subjek penelitian tersebut berinisial $\mathrm{U}$, YM, dan PH, terdapat informan pendukung yang terdiri dari dua orang yaitu $\mathrm{M}$ sebagai Pembina Karang Taruna dan A sebagai Pengurus BPD bagian kepemudaan. Ketiga subjek penelitian ini adalah Pengurus Inti Karang Taruna Desa Bunisari termasuk dalam usia produktif, sehingga pada usia tersebut subjek sudah bekerja. Ketiga subjek memiliki pendidikan SLTA, tingkat pendidikan berpengaruh terhadap cara pandang dan pengetahuan umum subjek, namun untuk keaktifan dalam kepengurusan karang taruna sangat aktif karena YM bekerja sebagai buruh harian lepas, sehingga memiliki waktu fleksibel. Kemudian PH karena bekerja sebagai wiraswasta sehingga sedikit lebih fleksibel, sedangkan $U$ karena bekerja sebagai satpam dan lokasi bekerja tidak di Desa Bunisari mengakibatkan waktu yang dimiliki U terbatas.

Kepercayaan (trust) dalam menangani kemiskinan, kepercayaan adalah salah satu unsur modal sosial berbentuk keinginan untuk mengambil resiko dalam hubungan-hubungan sosial yang didasari oleh perasaan yakin bahwa yang lain akan melakukan sesuatu seperti yang diharapkan dan akan bertindak dalam suatu pola tindakan yang saling mendukung dan menguatkan. Kepercayaan pengurus karang taruna dalam menangani kemiskinan mengacu pada keyakinan dari masyarakat terhadap pengurus karang taruna, percaya terhadap diri sendiri dapat menangani masalah keluarga miskin bersama pengurus karang taruna lain, kemampuan menguatkan keyakinan pengurus karang taruna lain dalam menangani kemiskinan, kesadaran penting pengurus karang taruna untuk menangani kemiskinan, penegakan kejujuran, penguatan komitmen, dan penguatan perilaku kooperatif serta harapan pengurus karang taruna terhadap organisasi karang taruna dalam menangani kemiskinan. Mengenai keyakinan masyarakat terhadap pengurus karang taruna dalam menangani kemiskinan di Desa Bunisari sudah kuat, 
ketiga subjek meyakini telah dipercaya masyarakat untuk menangani masalah keluarga miskin di Desa Bunisari. Hal ini atas pertimbangan bahwa pengurus karang taruna dipilih berdasarkan musyawarah masyarakat. Karang taruna juga sering dilibatkan dalam kegiatan sosial yang berhubungan dengan masyarakat seperti pemberian bantuan sosial, sehingga interaksi sosial antara pengurus karang taruna dengan masyarakat dekat dan terjalin dengan baik. Hal ini menunjukkan bahwa hubungan pengurus karang taruna memang sudah dekat dengan masyarakat karena pengurus karang taruna sering membantu masyarakat yang sedang kesusahan untuk membantu masyarakat mengalami kesulitan. Informasi informan A menjelaskan bahwa pengurus karang taruna biasa membantu menghubungkan warga yang sakit untuk mengakses mobil ambulance desa guna membawa warga yang sakit tersebut ke rumah sakit.

Selain memiliki keyakinan dipercaya masyarakat pengurus karang taruna juga perlu percaya terhadap diri sendiri bahwa diri subjek dapat menangani masalah keluarga miskin di Desa Bunisari bersama pengurus karang taruna lainnya, karena percaya terhadap diri sendiri dapat meningkatkan motivasi dan semangat pengurus karang taruna. Motivasi yang muncul dari dalam diri lebih bertahan lama. Sebagaimana yang disampaikan oleh Subjek U mengenai kepercayaan diri U yang cukup tinggi bahwa U mampu membantu menangani masalah keluarga miskin di Desa Bunisari karena sudah berusaha melakukan yang terbaik seperti ikut mengawasi jalannya pemberian bantuan.

Norma (Norms) yang dianut subjek dalam menangani kemiskinan, Norma adalah sekumpulan aturan yang diharapkan dipatuhi dan diikuti oleh anggota masyarakat pada suatu entitas sosial tertentu, biasanya terinstitusionalisasi, mengandung sanksi sosial yang dapat mencegah individu berbuat menyimpang dari kebiasaan yang berlaku di masyarakat. Norma adalah salah satu aspek dalam modal sosial, sehingga untuk mengetahui seberapa berpengaruh modal sosial pengurus karang taruna dalam menangani masalah kemiskinan di Desa Bunisari maka perlu diketahui apakah terdapat norma sosial dalam pengurus karang taruna, implementasi norma adalah adanya aturan yang disepakati bersama oleh sebab itu perlu diketahui aturan yang berlaku dalam kepengurusan karang taruna guna menangani kemiskinan. Bagaimana aturan tersebut mempengaruhi kinerja pengurus karang taruna, seperti apa aturan tersebut mengikat pengurus karang taruna, bagaimana kendala menjalankan aturan tersebut, sanksi apa yang diberikan, apakah potensi pengurus karang taruna tergali dengan adanya aturan, dampak adanya aturan terhadap usaha menangani kemiskinan, dan keefektifan aturan terhadap usaha menangani kemiskinan, Untuk mengetahui keberadaan norma sosial dalam kepengurusan karang taruna maka perlu menggali mengenai apakah karang taruna memiliki aturan-aturan yang biasa diterapkan oleh pengurus karang taruna terutama dalam menangani masalah keluarga miskin di Desa Bunisari dan bagaimana aturan tersebut berlaku jika ada.

Ternyata Pengurus Karang Taruna Desa Bunisari belum memiliki aturanaturan yang disepakati bersama terutama untuk menangani masalah keluarga miskin. Aturan yang disepakati bersama antar pengurus karang taruna belum ada, pengurus karang taruna bertindak selayaknya penduduk desa umumnya. Hal ini menunjukkan bahwa belum adanya kesadaran mengenai pentingnya ada aturan 
bersama guna menjaga keseimbangan hubungan dalam organisasi. Subjek U hanya mengingatkan tentang pentingnya gotong royong. Sama halnya dengan yang dikemukakan oleh subjek U, dalam Kepengurusan Karang Taruna Desa Bunisari ini memang belum memiliki aturan yang disepakati Bersama.

Meskipun sudah berusaha keras agar karang taruna di desanya terus aktif dengan membuat ajakan untuk saling berkomunikasi dan saling melengkapi, namun karena masih berupa ajakan dan belum menjadi aturan yang disepakati bersama, sehingga belum semua melaksanakan ajakan tersebut. Subjek PH menambahkan bahwa dalam kepengurusan karang taruna tidak ada aturan khusus yang harus ditaati oleh pengurus, $\mathrm{PH}$ hanya sering menganjurkan kepada pengurus karang taruna lainnya agar dalam berkegiatan selalu menegakkan keterbukaan. Keterbukaan adalah salah satu bentuk dari usaha menjaga kemurnian dari kepercayaan itu sendiri, keterbukaan yang dimaksud memiliki arti yang luas, selain terbuka mengenai urusan dana terbuka disini juga bersedia berbagi cerita terhadap pengurus lain mengenai kondisi yang sedang dihadapi, agar nantinya antar pengurus bisa saling menolong dan saling melengkapi serta tidak ada buruk sangka karena sudah saling memahami kondisi masing-masing.

Berdasarkan pernyataan subjek, karang taruna belum memiliki aturan yang disepakati bersama, subjek hanya memberikan anjuran dalam kepengurusan karang taruna sesuai nilai yang diyakini, ada yang menganjurkan agar gotong royong, agar saling komunikasi dan melengkapi serta ada yang mengajak agar terbuka. Penggalian lebih dalam mengenai aturan atau nilai yang subjek yakini mempengaruhi kinerja pengurus karang taruna dalam usaha menangani masalah keluarga miskin di Desa Bunisari.
Belum adanya aturan yang disepakati bersama sehingga kinerja karang taruna belum dapat diukur berdasarkan ketaatan terhadap aturan bersama dalam usaha menangani masalah keluarga miskin di Desa Bunisari. Anjuran untuk gotong royong belum dapat disebut sebagai aturan bersama karena tidak ada kesepakatan. Pengurus karang taruna dalam berkegiatan keorganisasian karang taruna bersifat sukarela, sehingga pengurus karang taruna melakukan aktif bvitas tidak berdasarkan aturan yang disepakati bersama.

Penjelasan tersebut menunjukkan bahwa belum ada aturan yang disepakati bersama membuat kinerja pengurus karang taruna dalam usaha menangani masalah kemiskinan di Desa Bunisari belum dapat diukur baik buruknya, namun terlihat bahwa belum ada aturan membuat kinerja pengurus karang taruna belum maksimal. Hal ini terlihat dari adanya pengurus karang taruna yang tidak aktif, sehingga memberatkan tugas pengurus karang taruna yang lain karena mengerjakan tugas pengurus yang tidak aktif. Penggalian lebih dalam terkait anjuran dari pengurus karang taruna apakah mengikat seluruh pengurus karang taruna atau tidak perlu dilakukan, bagaimana proses tata tertib tersebut diterima dan mengikat seluruh pengurus karang taruna jika memang mengikat. Ternyata anjuran tersebut tidak mengikat.

Hasil wawancara dengan subjek YM menunjukkan bahwa karang taruna belum memiliki aturan bersama, sehingga para pengurus tidak terikat, yang dilakukan subjek hanya memberikan ajakan. Pada dasarnya modal sosial baru dapat diidentifikasi jika antar aktor melakukan interaksi sosial, aktor tersebut adalah subjek dan pengurus karang taruna lainnya. Ketika interaksi sosial yang terjalin melibatkan banyak aktor dengan kepentingan bervariasi dan derajat 
toleransinya juga sangat beragam maka memang sulit untuk mengembangkan kondisi saling menghargai atau memberikan perhatian (a mutual recognition), kondisi semacam ini dapat diatasi manakala setiap pihak bersedia untuk saling berkorban, pengorbanan yang dilakukan bisa berupa waktu, tenaga dan sumber daya. Oleh karena itu dibutuhkan kesepakatan dari semua pihak yaitu pengurus karang taruna untuk membuat aturan bersama demi tercapainya tujuan bersama meskipun nanti akan ada beberapa hal yang dikorbankan.

Belum ada aturan yang disepakati bersama sehingga belum diketahui apakah ada pengurus karang taruna yang melanggar aturan atau tidak, dan tidak ada sanksi yang diberikan, dari kenyataan dapat diketahui bahwa aturan bersama ini penting dimiliki oleh organisasi karang taruna agar keberjalanan budaya organisasi terus ke arah lebih baik, apabila organisasi tidak memiliki aturan yang diyakini bersama maka pengurus organisasi akan bertindak semaunya dan kurang bertanggungjawab. Seperti yang dijelaskan Nan Lin bahwa adanya sanksi dapat meningkatkan trust (keyakinan terhadap nilai-nilai yang positif yang mampu menciptakan perubahan) dan adanya sanksi dapat meningkatkan kerjasama saling menguntungkan. Gambaran mengenai apakah dengan adanya ajakan tersebut dapat menggali potensi setiap pengurus karang taruna dalam proses menangani masalah keluarga miskin di Desa Bunisari.

Jejaring sosial (social network) subjek dalam menangani kemiskinan, Jejaring sosial merupakan hubungan-hubungan yang tercipta antar banyak individu dalam suatu kelompok ataupun antar kelompok dengan kelompok lainnya atau lembaga terkait organisasi tersebut. Hubungan-hubungan yang terjadi bisa dalam bentuk formal ataupun bentuk informal. Jejaring sosial akan kuat tergantung pada kapasitas yang ada dalam kelompok masyarakat untuk membangun sejumlah asosiasi berikut membangun jejaringnya. Salah satu keberhasilan membangun modal sosial terletak pada kemampuan sekelompok orang dalam suatu asosiasi atau perkumpulan untuk melibatkan diri dalam suatu jejaring sosial. Pernyataan tersebut dapat disimpulkan bahwa jejaring sosial merupakan salah satu aspek yang penting dalam modal sosial karena melalui jejaring sosial dapat diketahui seberapa besar suatu aktor atau kelompok membangun kerjasama dengan aktor atau kelompok lain untuk membangun hubungan sosial yang bersifat saling menguntungkan dan timbal balik (reciprocal relationship). Jejaring sosial mengacu pada bagaimana pengurus karang taruna bermitra dengan dunia usaha, Dinas Ketenagakerjaan Kabupaten Cianjur, Dinas Sosial Kabupaten Cianjur, Dinas Pendidikan dan Kebudayaan Kabupaten Cianjur, Dinas Kesehatan Kabupaten Cianjur, Dinas Pertanian Kabupaten Cianjur.Kendala yang dihadapi dalam membangun kemitraan baik dalam internal pengurus karang taruna maupun lintas sektoral dalam proses menangani masalah kemiskinan, cara mengatasi kendala dalam membangun kemitraan baik dari internal pengurus karang taruna maupun lintas sektoral dalam menangani masalah kemiskinan.

Pengurus karang taruna membangun jejaring sosial perlu penggalian lebih dalam apakah pengurus karang taruna bermitra dengan dunia usaha dalam menangani masalah keluarga miskin di Desa Bunisari, jika ada kemitraan dengan dunia usaha maka perlu penelusuran bagaimana bentuk kemitraan dengan dunia usaha. Bentuk kemitraan jejaring sosial yang dimiliki karang taruna masih terbatas terutama untuk meningkatkan keuntungan ekonomi 
(economic gian), sehingga kemampuan untuk menangani masalah kemiskinan melalui cara bermitra dengan dunia usaha masih belum maksimal. Tetapi sudah terlihat ada motivasi dan kemauan dari pengurus karang taruna untuk mencari peluang. Hal ini menunjukkan pada dasarnya pengurus karang taruna sudah ada kemauan untuk membangkitkan perekonomian di desanya namun karena akses masih sulit, sehingga kemitraan "Ada mitra dengan dunia usaha seperti Gudang alfa bentuk kemitraannya limbah kardusnya buat desa ini, kerjasama dengan warga yang membuat peci rajut karang taruna itu bantu promosiin, kerjasama dengan penerima hasil panen lele kaya warung pecel lele lesehan pinggir jalan gitu, ada kerjasama dengan pengepul barang bekas juga untuk mengambil hasil sampah jual dari bank sampah." (Kerjasama yang dijalin dengan dunia usaha meliputi kerjasama dengan gudang alfamart, bentuk kerjasamanya limbah kardus dari gudang alfamart diserahkan ke desa ini, kerjasama dengan pengrajin peci rajut bentuk kemitraan yang dibangun adalah karang taruna membantu promosi pemasaran, kemudian kerjasama dengan pedagang lesehan terkait hasil panen ikan lele, dan kerjasama dengan pengepul barang bekas terkait hasil sampah jual dari bank sampah).

Berdasarkan penuturan Subjek PH, untuk kemitraan antara pengurus karang taruna dengan dunia usaha sudah cukup banyak meskipun kemitraan yang dibangun belum dalam skala besar, tetapi usaha tersebut sudah menunjukkan kinerja yang baik dari pengurus karang taruna. Hal ini sesuai dengan pernyataan $\mathrm{PH}$ bahwa pengurus sudah menjalin kemitraan dengan terjalin masih tergolong kurang. Seandainya karang taruna benar-benar serius bekerja sama dengan dunia usaha dan meningkatkan kualitas dan kuantitas produk Desa Bunisari maka suatu saat Desa Bunisari dapat memiliki produk khas yang menjadi komoditas andalan.

Subjek PH juga menyampaikan penjelasannya terkait kemitraan yang dibangun karang taruna dengan dunia usaha sebagai berikut:

pengrajin peci rajut kerja sama yang baru terbangun adalah pemasaran produknya, pengurus karang taruna dapat melakukan inovasi dalam pemasarannya misalnya memanfaatkan internet agar target pasar juga semakin luas dan dapat dilakukan inovasi terhadap produk peci juga agar lebih menarik dan unik, kemitraan dengan pedagang pecel lele pinggir jalan adalah dengan menjual hasil panen ikan lele para anggota karang taruna kepada pedagang pecel lele kecil dipinggir jalan inovasi dapat dilakukan karang taruna adalah modifikasi terhadap metode budidaya agar lebih efektif dan hasil lebih banyak, dengan gudang alfamart dapat memperluas kerjasama selain menerima limbah kardusnya, dapat dilakukan kerjasama lain seperti inovasi membuat produk yang banyak dicari orang untuk kemudian dititipkan di Alfamart dan dipasarkan secara online.

Karang taruna Desa Bunisari memang cukup banyak membangun kerjasama dengan dunia usaha, tetapi kerjasama yang dibangun belum terencana dengan baik, seperti saat ada bank sampah pengurus karang taruna bekerja sama dengan pengepul barang bekas untuk menjual sampah yang memiliki nilai jual dari warga, pada awalnya pengurus karang taruna semangat mengambil sampah dari warga, kemudian warga menukar hasil penjualan sampahnya setelah satu bulan 
kepada karang taruna dalam bentuk pulsa listrik. Lalu karang taruna menjual sampah yang terkumpul dari warga ke pengepul barang bekas, namun saat ini pengurus karang taruna sudah tidak menarik sampah ke warga karena terbatasnya SDM dan alat angkut, sehingga warga yang bersedia menyetor saja ke karang taruna yang masih dilayani untuk menabung sampah. Hal ini menunjukkan terjadi penurunan kerjasama dengan pengepul barang bekas karena berkurang juga warga yang menabung sampah.

Karang taruna bermitra dengan dunia usaha sudah cukup banyak namun kemitraan yang dibangun cakupannya masih kecil sehingga belum berdampak terlalu luas. Hal ini berpengaruh terhadap terbatasnya keuntungan ekonomi (economic gain). Namun banyak kemitraan yang dibangun dengan dunia usaha sudah menunjukkan bahwa pengurus karang taruna memiliki motivasi dan semangat yang tinggi, yang perlu dilakukan disini adalah meningkatkan kreatifitas dan inovasi pengurus karang taruna dalam kemitraan yang dibangun dengan dunia usaha agar manfaat yang dihasilkan lebih luas lagi. Penting untuk digali apakah pengurus karang taruna membangun jejaring dengan Dinas Ketenagakerjaan Kabupaten Cianjur dalam menangani masalah keluarga miskin yang tidak bekerja di Desa Bunisari. Subjek U menyampaikan mengenai jejaring dengan Dinas Ketenagakerjaan Kabupaten Cianjur.

Pengurus karang taruna sektoral dengan Dinas Sosial Kabupaten Cianjur dalam menangani masalah keluarga miskin yang tidak mendapatkan program sosial dari pemerintah di Desa Bunisari di butuhkan untuk memberikan gambaran mengenai kerjasama antara pengurus karang taruna dengan Dinas Sosial. Untuk menguatkan jejaring sosial dibutuhkan usaha pertukaran sosial antar aktor yaitu antara karang taruna dengan pihak Dinas Sosial, agar nantinya terbentuk relasi yang mapan (a presistent relationship). Oleh karena itu dibutuhkan usaha dari aktor untuk memperoleh sistem sumber dari aktor lain dalam kondisi ini dari Dinas Sosial, pihak karang taruna diharapkan mampu membangun dan memelihara relasi-relasi sosial (maintenance of social relationship) yang mapan dan stabil. Ketika relasi sudah terbangun maka akan muncul trust, komitmen dan hubungan reciprocal yaitu hubungan saling membutuhkan. Apabila jejaring yang dibangun pengurus karang taruna dengan Dinas Sosial dilanjutkan kedepannya akan saling memberikan keuntungan ekonomi yaitu mulai tercukupinya kebutuhan dengan mudah, dan akan mendapat manfaat sosial yaitu dalam masyarakat terciptanya keeratan interaksi sosial dan saling percaya sehingga tidak ada keraguan untuk saling menolong.

Sehubungan dendan hal tersebut Dinas Sosial merupakan dinas yang paling berhubungan dengan masalah keluarga miskin dan pemberian bantuan sosial, namun terlihat berdasarkan penuturan subjek PH hubungan pengurus karang taruna dengan Dinas Sosial tidak terjalin dengan erat, karang taruna belum memanfaatkan dengan maksimal adanya Dinas Sosial. Apabila karang taruna dapat memanfaatkan dengan maksimal keberadaan Dinas Sosial seharusnya pengurus karang taruna inisiatif membangun jejaring dengan Dinas Sosial agar mempermudah mendapat akses informasi terkait penanganan masalah keluarga miskin. Dibutuhkan usaha lebih besar lagi dari pengurus karang taruna untuk membuat kemitraan dengan Dinas Sosial. 
Diketahui bahwa kerjasama yang dilakukan antara karang taruna dengan Dinas Sosial Kabupaten Cianjur masih sebatas mengikuti bimbingan teknis untuk kelancaran proses pemberian program sosial dari pemerintah namun belum terjalin kerjasama dengan Dinas Sosial dimana karang taruna yang proaktif dan berinisiatif mengajak untuk melakukan kerjasama dalam usaha menangani masalah kemiskinan. Dalam menangani masalah keluarga miskin yang tidak mendapatkan program bantuan sosial dari pemerintah yang dilakukan pengurus karang taruna adalah mendata kemudian mengusulkan ke desa identitas keluarga miskin tersebut setelah itu desa yang melakukan tindak lanjut berikutnya.

Keterlibatan Dinas Pendidikan dan Kebudayaan Kabupaten Cianjur dalam membantu usaha karang taruna menangani masalah keluarga miskin yang memiliki pendidikan rendah di Desa Bunisari, membantu usaha pengurus karang taruna menangani keluarga miskin yang memiliki pendidikan rendah. Walaupun belum mencari akses secara maksimal untuk membuka pintu kerjasama dengan Dinas Pendidikan dan Kebudayaan Kabupaten Cianjur, tetapi ada kesadaran dari pengurus karang taruna untuk melakukan intervensi terhadap masalah kemiskinan melalui pendidikan. Hal ini penting dalam menangani kemiskinan, jika keluarga miskin mampu mengakses pendidikan maka memperbesar peluang mendapatkan pekerjaan lebih layak.

Keterlibatan Dinas Pendidikan dan Kebudayaan Kabupaten Cianjur dalam membantu usaha karang taruna menangani masalah keluarga miskin yang memiliki pendidikan rendah masih minim. Jika keluarga miskin dapat mengakses pendidikan maka peluang untuk memperoleh pekerjaan yang layak akan semakin terbuka dan perekonomian keluarga miskin tersebut bisa meningkat. Selain pendidikan, hal penting dalam mendukung penanganan kemiskinan adalah kesehatan oleh karena itu perlu dipahami bagaimana kemitraan karang taruna dengan Dinas Kesehatan Kabupaten Cianjur dalam menangani masalah keluarga miskin yang memiliki kesehatan rendah di Desa Bunisari, YM juga menyampaikan mengenai kemitraan dengan Dinas Kesehatan Cianjur masih terbatas.

\section{PEMBAHASAN}

Kepercayaan pengurus karang taruna dalam usaha menangani kemiskinan di Desa Bunisari sudah kuat, hal ini didukung oleh banyak faktor, seperti keyakinan dari masyarakat terhadap pengurus karang taruna, dimana subjek meyakini telah dipercaya masyarakat untuk menangani masalah keluarga miskin di Desa Bunisari. Hal ini atas pertimbangan bahwa pengurus karang taruna dipilih berdasarkan musyawarah masyarakat kemudian karang taruna juga sering dilibatkan dalam kegiatan sosial yang berhubungan dengan masyarakat seperti pemberian bantuan dan sebagainya sehingga interaksi sosial antara pengurus karang taruna dengan masyarakat juga sudah dekat dan terjalin dengan baik.

Ketiga subjek percaya terhadap diri sendiri bahwa subjek mampu menangani masalah kemiskinan di Desa Bunisari bersama pengurus karang taruna lainnya. seperti dalam pernyataan $U$ yang memiliki motivasi tinggi untuk melakukan yang terbaik saat membantu masyarakat, lalu YM yang ingin berkontribusi maksimal untuk Desa Bunisari, dan PH yang meyakini bahwa setiap yang terlahir ke bumi pasti membawa kebermanfaatan, begitu juga subjek sebagai pengurus karang 
taruna dapat membawa kebermanfaatan untuk masyarakat.

Kemampuan menguatkan keyakinan pengurus karang taruna lain dalam menangani kemiskinan ketiga subjek sudah kuat selama ada koordinasi, kerjasama, dan sinergi dari berbagai pihak seperti pemerintah Desa, Pengurus karang taruna, anggota karang taruna, serta masyarakat pada umumnya. Seperti yang dikatakan U bahwa untuk menguatkan keyakinan dibutuhkan dukungan dari berbagai pihak, lalu yang dikatakan YM untuk menguatkan keyakinan dengan menjalankan tugas sesuai peran dengan baik sedangkan $\mathrm{PH}$ dalam menguatkan keyakinan dengan membangun sinergi dan kerjasama dengan berbagai pihak.

Ketiga subjek merasa penting bagi pengurus karang taruna untuk menangani masalah keluarga miskin di Desa Bunisari seperti yang dinyatakan $U$ bahwa pengurus karang taruna adalah garda terdepan organisasi sosial kepemudaan di desa Bunisari sehingga masa depan desa ada ditangan pemuda-pemudi dan pengurus karang taruna merupakan bagian dari pemuda berusia produktif Desa Bunisari, kemudian YM menjelaskan bahwa masalah kemiskinan adalah masalah bersama sehingga harus diselesaikan bersama, lalu PH menyebutkan keterlibatan Pengurus karang taruna sangat penting tetapi tidak bisa sendirian butuh kerjasama dan saling melengkapi antar pihak.

Subjek sepakat bahwa karang taruna sudah menegakkan kejujuran, seperti penjelasan dari $U$ untuk menegakkan kejujuran dengan cara transparan dalam hal apapun, kemudian YM menegakkan kejujuran dengan cara, selama proses pendataan penerima bantuan, pengurus karang taruna mendata apa adanya tidak ada kecurangan dan pengurus karang taruna berusaha mengawasi jalannya pemberian bantuan agar tepat sasaran, karena kejujuran adalah salah satu cara menjaga kepercayaan.

Cara menguatkan komitmen yang dilakukan subjek dengan pengurus karang taruna lainnya dalam menangani masalah keluarga miskin adalah dengan memberikan teladan untuk berkomitmen terhadap peran di kepengurusan, melibatkan pengurus karang taruna lainnya agar teribat aktif, pemberian keyakinan agama bahwa dengan diniatkan ibadah maka akan berbuah pahala, selain itu untuk menguatkan komitmen juga dilakukan dengan cara saling berusaha tidak merugikan satu sama lain.

Cara yang dilakukan ketiga subjek dalam menguatkan perilaku kerjasama adalah dengan memberikan edukasi pentingnya menangani masalah kemiskinan, selain itu cara yang dilakukan adalah menganggap semua sebagai rekan kerja tidak ada atasan dan bawahan serta semua kegiatan dilakukan bersama-sama, selain itu yang dilakukan adalah sering mengajak berkumpul, berdiskusi dan menyamakan persepsi dan tujuan untuk bekerja sama menangani masalah kemiskinan bersama.

Harapan ketiga subjek terhadap karang taruna dalam menangani masalah keluarga miskin di Desa Bunisari adalah dimasa depan pengurus karang taruna memiliki kepedulian sosial lebih tinggi, lebih kreatif, lebih inovatif, dan lebih solid relasi sosial serta komunikasi antar pengurus maupun dengan pihak lain menjadi lebih baik dengan begitu maka masalah keluarga miskin di Desa Bunisari dapat ditangani dengan baik.

Norma sosial adalah salah satu aspek dalam modal sosial sehingga untuk mengetahui seberapa berpengaruh modal sosial pengurus karang taruna dalam 
menangani masalah kemiskinan di Desa Bunisari maka juga harus diketahui apakah terdapat norma sosial dalam pengurus karang taruna, perlu mengetahui aturan yang berlaku dalam kepengurusan karang taruna guna menangani kemiskinan dan berdasarkan penyataan subjek ternyata belum ada norma sosial yang berlaku dalam kepengurusan karang taruna untuk menangani kemiskinan, subjek hanya memberikan anjuran sesuai yakinan masing-masing dan belum ada kesepakatan bersama untuk mentaatinya. Karena tidak ada aturan bersama artinya tidak mempengaruhi kinerja pengurus karang taruna, tidak ada yang mengikat pengurus karang taruna, tidak ada kendala dalam menjalankan aturan, tidak ada sanksi, tidak ada potensi yang tergali, tidak ada dampak, tidak diketahui tingkat keefektifan aturan karena aturan belum di buat dan diterapkan.

Ketidakadaannya aturan dalam tubuh organisasi hal ini dalam jangka panjang akan berdampak buruk pada organisasi itu sendiri, pengurus lama-lama akan kehilangan keaktifan pengurus lainnya karena tidak adanya aturan dan sanksi yang disepakati bersama untuk dipatuhi padahal adanya norma atau aturan bersama dalam organisasi memiliki manfaaat untuk meningkatkan trust dan solidaritas sosial suatu organisasi. Adanya sanksi terhadap setiap penyimpangan yang terjadi dapat membantu proses pendidikan budaya organisasi terhadap pengurus organisasi, dan juga dapat meningkatkan perasaan menjadi bagian dari komunitas dan meningkatkan sense of community. Oleh karena itu diharapkan pengurus karang taruna Desa Bunisari agar membuat norma atau aturan yang disepakati bersama guna kebaikan dan masa depan organisasi karang taruna. Agar semua pengurus tidak ada yang dirugikan.
Jejaring sosial antar pengurus karang taruna belum terbangun dengan maksimal, terkendala oleh keaktifan pengurus karang taruna yang belum semuanya terlibat aktif dalam setiap kegiatan karang taruna, dari lima belas pengurus yang aktif sebanyak sembilan orang hal ini mempersempit jaringan internal pengurus karang taruna karena intensitas pertemuan diskusi dan penyamaan persepsi juga terbatas, membuat arah gerak pengurus karang taruna juga terbatas. Dalam istilah untuk bonding social capital yang terdiri dari ikatan pertemanan, satu daerah sudah kuat tetapi lingkupnya sempit, dan untuk bridging social capital yang lingkupnya lebih luas yaitu organisasi masih rendah kemudian untuk jaringan pengurus karang taruna dengan lintas sektoral jika dengan dunia usaha untuk linking social capital sudah cukup baik tetapi untuk linking social capital dengan dinas-dinas terkait seperti dinas pendidikan dan kebudayaan, kesehatan, pertanian, sosial, dan ketenagakerjaan jejaring sosial yang dibangun masih rendah bahkan ada yang belum terjalin, hal ini terjadi karena belum ada keberanian dari pengurus karang taruna untuk membuka akses dan mencari link, dan membuka komunikasi dengan dinas-dinas terkait. Oleh karena itu dibutuhkan kemauan dari pengurus karang taruna untuk berkorban waktu, tenaga, dan biaya untuk membangun jaringan dengan pihak lainnya demi terciptanya jaringan yang besar guna mendukung usaha menangani kemiskinan di Desa Bunisari. Setelah disadari pentingnya jejaring sosial baik dalam internal pengurus maupun eksternal yaitu hubungan lintas sektoral maka diharapkan semua pihak bisa mulai bersinergi.

Proses penanganan masalah keluarga miskin oleh pengurus karang taruna dapat terlaksana dengan baik apabila modal sosial 
yaitu kepercayaan, norma sosial, dan jejaring sosial dapat ditumbuhkan dengan baik. Timbulnya masalah ketika bagian dari modal sosial belum maksimal dalam kepengurusan karang taruna sehingga menghambat proses penanganan kemiskinan yang dilakukan oleh organisasi karang taruna, apabila modal sosial pengurus karang taruna dapat dioptimalkan maka proses penganan kemiskinan di Desa Bunisari menjadi maksimal karena kekuatan kepercayaan, norma sosial, dan jejaring sosial dapat dimanfaatkan oleh pengurus karang taruna.

Hasil penelitian menunjukkan bahwa modal sosial memiliki pengaruh yang besar terhadap proses penanganan kemiskinan yang dilakukan pengurus karang taruna, karena modal sosial yang terdiri dari kepercayaan, norma sosial, dan jejaring sosial sangat mempengaruhi proses dan hasil kinerja pengurus karang taruna dalam menangani masalah keluarga miskin. Bagian modal sosial pengurus karang taruna yang sudah menunjukkan hasil bagus adalah kepercayaan, selanjutnya jejaring sosial masih kurang, dan norma sosial masih sangat kurang. Hal ini terjadi karena banyak faktor seperti belum di implementasikannya nilai-nilai sosial yang ada dalam kepengurusan karang taruna, sikap pengurus karang taruna yang belum semuanya memprioritaskan kepengurusan karang taruna, dan kesibukan pengurus karang taruna dalam memenuhi kebutuhan hidupnya, kemudian untuk jejaring sosial belum yang dibangun pengurus karang taruna juga masih sempit

$$
\text { Pernyataan subjek yang }
$$

menunjukkan bahwa kendala utama yang menyebabkan proses penanganan masalah keluarga miskin di Desa Bunisari terhambat adalah terletak pada implementasi dari norma sosial dan sempitnya jejaring sosial pengurus karang taruna:

\section{Norma sosial}

Nilai-nilai sosial yang ada dalam diri pengurus karang taruna belum semuanya di implementasikan dengan baik, sehingga masih ada pengurus karang taruna yang belum aktif, tanggungjawab pengurus karang taruna menjadi belum jelas, dan tidak ada sanksi yang disepakati bersama untuk membuat organisasi karang taruna semakin kuat dan rapi.

2. Jejaring sosial

Jejaring sosial yang dibangun pengurus karang taruna masih minim, dimana kemitraan yang terbentuk lingkupnya masih sempit dan dampaknya juga masih sempit sehingga belum efektif untuk menangani kemiskinan yang ada didalam masyarakat. Hal ini terjadi karena pengurus karang taruna belum memiliki kemampuan untuk membangun jejaring sosial dan memetakan sistem sumber yang dapat dimanfaatkan untuk menangani kemiskinan

\section{SIMPULAN}

Karang Taruna Desa Bunisari memiliki kekhasan dibanding dengan karang taruna desa lainnya, karang taruna desa ini memiliki kegiatan untuk penanganan kemiskinan seperti bank sampah, catering, ternak lele dan sebagainya. Namun pada kenyataanya karang taruna di desa ini belum mampu memaksimalkan kekhasan yang dimilikinya untuk membantu penanganan masalah kemiskinan di Desa Bunisari. Hal ini terjadi karena modal sosial dalam pengurus karang taruna belum dikembangkan dengan optimal sehingga proses penanganan kemiskinan pengurus karang taruna juga mengalami kendala. 
Modal sosial pengurus karang taruna dalam menangani masalah kemiskinan terdiri dari tiga bagian yaitu kepercayaan, norma, dan jejaring sosial. Hasil penelitian modal sosial yang masih kurang adalah norma sosial dan jejaring sosial. Untuk norma sosial karena belum adanya penerapan norma dalam bentuk komitmen bersama untuk menangani kemiskinan sehingga tidak ada yang mengikat pengurus karang taruna dan tidak ada sanksi sosial bagi pengurus karang taruna yang melakukan penyimpangan. Kendala membangun jejaring sosial dalam internal pengurus adalah minimnya interaksi dengan pengurus lainnya karena kumpul dilaksanakan insidental, kendala dalam membangun jejaring sosial lintas sektoral adalah jejaring yang dibangun masih insidental sehingga pengaruh yang dihasilkan sempit karena ketidakberanian dan ketidaktahuan pengurus bagaimana memulai komunikasi dan relasi dengan

\section{DAFTAR PUSTAKA}

Agus Sjafari. (2014). Kemiskinan dan Pemberdayaan Kelompok. Yogyakarta: Graha Ilmu.

Amiruddin. (2016). Metode Penelitian Sosial. Yogyakarta: Parama Ilmu.

Edi Suharto. (2014). Membangun Masyarakat Memberdayakan Rakyat. Cetakan Kelima. Bandung: Refika Aditama.

Farra Aprilia Kawalod, Arie Rorong, Verry V. Londa. 2015. Peran Organisasi Karang Taruna dalam Pemberdayaan Masyarakat Desa. JAP No 31 Vol III. https://ejournal.unsrat.ac.id/inde x.php/JAP/article/view/8737/8298 (diakses pada tanggal 19 Agustus 2019).

Irawan Soehartono.(2015). Metode Penelitian Sosial. Bandung: PT Remaja Rosdakarya. sistem sumber lain tersebut.

Usulan program untuk meningkatkan penerapan norma dan jejaring sosial pengurus karang taruna adalah Forum Diskusi bagi Pengurus Karang Taruna Desa Bunisari untuk Menguatkan Modal Sosial. Metode yang digunakan adalah bekerja dengan komunitas (community work) melalui pendekatan partisipasi aktif masyarakat lokal (locality development). Teknik yang digunakan adalah Focus Group Discussion yaitu diskusi kelompok terarah. Latar belakang digunakan teknik FGD adalah memberikan ruang lebih luas bagi pengurus karang taruna untuk mendiskusikan masalahnya, lalu memberikan usulan solusi dan pada akhirnya menerapkan solusi yang di usulkan. Diharapkan dengan cara tersebut program akan berdampak nyata dan berkesinambungan.

John Field. (2010). Modal Sosial (Social Capital). Edisi Indonesia. Nurhadi (Penerjemah). Inyak Rizar Mudzir. Bantul: Kreasi Wacana.

Jousairi Hasbullah. (2006). Social Capital: Menuju Keunggulan Budaya Manusia Indonesia. Jakarta: MRUnited Press.

Moleong, Lexi J. (2012). Metodologi Penelitian Kualitatif. Cetakan Ketigapuluh. Bandung: PT Remaja Rosda Karya.

Robert M.Z. Lawang. (2004). Kapital Sosial dalam Perspektif Sosiologik: Suatu Pengantar. Jakarta: Fisip UI Press

Rusydan Fathy. (2019). Modal sosial: konsep, inklusivitas, dan pemberdayaan masyarakat. Jurnal Pemikiran Sosiologi, Vol 6 (1) (https://journal.ugm.ac.id/jps/arti cle/download/47463/pdf) (diakses pada tanggal 06 Mei2020). 
Sunyoto Usman. 2018. Modal Sosial.

Yogyakarta: Pustaka Pelajar.

Yarlina Yacoub.(2012). Pengaruh Tingkat Pengangguran terhadap Kemiskinan di Kabupaten/ Kota Propinsi Kalimantan Barat. Volume 8, Nomor 3, Oktober 2012 hal 176 185.

http://riset.polnep.ac.id/bo/upload/p enelitian/penerbitan_jurnal/06eksos\%204\%20yarlina\%20okt12.p df

Yoshyane Wiharja, Dhyah Harjanti. (2016.) Perilaku CV. Anugrah Jaya dalam Menerapkan Modal Sosial untuk Mengembangkan Bisnis. Agora Vol $4 \quad$ No. 2. https://media.neliti.com/media/p ublications/55201-ID-none.pdf (diakses pada tanggal 28 September 2019).

Rusydan Fathy. (2019). Modal sosial: konsep, inklusivitas, dan pemberdayaan masyarakat. Jurnal Pemikiran Sosiologi, Vol 6 (1) (https://journal.ugm.ac.id/jps/arti cle/download/47463/pdf) (diakses pada tanggal 06 Mei2020).

Yarlina Yacoub.(2012). Pengaruh Tingkat Pengangguran terhadap Kemiskinan di Kabupaten/ Kota Propinsi Kalimantan Barat. Volume 8, Nomor 3, Oktober 2012 hal $176-185$. http://riset.polnep.ac.id/bo/upload /penelitian/penerbitan_jurnal/06eksos\%204\%20yarlina\%20okt12. pdf 